\title{
O DIREITO EXISTENCIAL À BUSCA DA FELICIDADE NA ANÁLISE LITERÁRIA DA OBRA O CAÇADOR DE PIPAS, DE KHALED HOSSEINI
}

\author{
William Paiva Marques Júnior ${ }^{1}$
}

\section{RESUMO}

A análise jurídica de obras literárias apresenta-se como eficaz mecanismo de abordagem interdisciplinar e transdisciplinar. A obra "O caçador de pipas" de Khaled Hosseini é fundamental na busca do direito existencial à felicidade ao retratar inquietações imanentes ao ser humano, universais e passíveis de uma visão que perpassa pelo campo do Direito. Os processos narrativos expostos pelo protagonista Amir despertam diversas questões relativas à felicidade como parâmetro hermenêutico do Direito Contemporâneo.

Palavras chaves: Direito existencial; busca; felicidade; análise literária; o caçador de pipas.

\section{THE EXISTENCIAL RIGHT TO SEARCH OF HAPPINESS IN LITERARY ANALYSIS OF WORK THE KITE RUNNER, OF KHALED HOSSEINI}

\section{ABSTRACT}

The juridical analysis of literary works presented as effective mechanism for interdisciplinary and transdisciplinary approach. The book "The Kite Runner" by Khaled Hosseini is essential in the quest for existential right to happiness to portray immanent concerns to human, universal and capable of a vision that moves through the field of law. The narrative processes exposed by the protagonist Amir arouse various issues related to happiness as hermeneutic parameter of Contemporary Law.

Keywords: Existencial right; search; happiness; literary analysis; the kite runner.

\section{INTRODUÇÃO}

Os mais diversos reclamos da sociedade e sentimentos humanos apresentam-se revelados em obras artísticas. Adultério, racismo, discriminação, conflitos familiares, afetividade em todas as suas manifestações, ódio, amor, guerras são temas recorrentes das obras artísticas (literárias e cinematográficas) em todas as épocas

\footnotetext{
1 Possui graduação em Direito (2001). Especialista em Direito Processual Penal pela ESMEC/UFC (2003). Mestre em Direito Constitucional pela Universidade Federal do Ceará (2009). Doutor em Direito Constitucional pela Universidade Federal do Ceará (2016). Professor Adjunto Nível 1 do Departamento de Direito Privado da Universidade Federal do Ceará, das disciplinas de Direito Civil II (Obrigações), Direito Civil V (Coisas) e Direito Agrário. Foi Advogado Júnior da ECT (Empresa Brasileira de Correios e Telégrafos) de 2008 a 2011. Coordenador de Graduação da Faculdade de Direito da UFC (2014 a 2017).Desde julho de 2017 ocupa o cargo de Assessor de Legislação e Normas da Pró-Reitoria de Gestão de Pessoas (PROGEP) da UFC. Editor-Chefe da Revista da Faculdade de Direito da UFC. Ex-bolsista de Doutorado da CAPES.
} 
da evolução cultural do ser humano que merecem uma reflexão à luz da Ciência do Direito.

O objetivo primordial do presente trabalho é o estudo dialógico e dialético nas interfaces existentes entre Direito, Cinema e Literatura, na mesma linha das tendências interdisciplinares utilizadas em outros sistemas jurídicos o que revela a deficiência no modelo brasileiro, na busca de uma análise mais percuciente sobre o tema ora em análise.

A construção histórica do multiculturalismo, plasmada em uma percepção dos direitos humanos como fonte inspiradora e limitadora das demandas oriundas de grupos minoritários (incluindo os refugiados). Existem duas concepções para o multiculturalismo: para a primeira, ele teria sido inspirado pelos direitos humanos universais, ao passo que a segunda aduz que a propagação do multiculturalismo acarreta um abandono dos direitos humanos universais, pois estes impõem uma cultura única, a qual massacra a singularidade das minorias. No contexto da contemporaneidade, o acesso à cidadania de grupos minoritários revela a decadência do juspositivismo legalista e a necessidade de repensar os métodos hermenêuticos clássicos. A partir destas constatações, o estudo dialógico do Direito, Cinema e Literatura adquire primariedade na investigação dos direitos fundamentais consagrados na ordem jurídicoconstitucional, especialmente na emergência de valores tão caros a grupos minoritários como o direito existencial à busca da felicidade de refugiados, estes entendidos como grupos minoritários.

A análise se funda em uma metodologia interdisciplinar e transdisciplinar, uma vez que enfoca os aspectos convergentes da Ciência do Direito com os múltiplos aspectos plasmados pelas manifestações artísticas e culturais oriundas do cinema e da literatura. Abandona-se a interpretação isolada dos fenômenos sociais por uma análise aberta aos fatos, reclamos e anseios presentes no campo artístico.

$\mathrm{O}$ romance $O$ caçador de pipas, de Khaled Hosseini, publicado pela primeira vez em 2003, permite ao leitor incursões em diversas dimensões que envolvem os dilemas e a alma humana. Diversos debates sociais, psicanalíticos e existenciais podem aflorar a partir do relato da trajetória de Amir e Hassan. Os processos narrativos expostos pelo protagonista Amir, despertam diversas questões no atinente à busca existencial da busca da felicidade como parâmetro hermenêutico do Direito Contemporâneo. 
Ressalte-se ainda a existência do filme $O$ caçador de pipas, dirigido pelo cineasta Marc Forster em 2008, adaptação do romance homônimo de Khaled Hosseini, revelando uma identificação estética entre a obra literária e a cinematográfica.

Trata-se de pesquisa bibliográfica com metodologia propositiva, dialética e pós-crítica, na medida em que se analisa o enfrentamento de uma temática que apresenta a sensibilidade concatenada à racionalidade, por meio da relação simbiôntica travada entre o Direito, a Literatura e o Cinema.

\section{LITERATURA E CINEMA COMO ELEMENTOS NECESSÁRIOS AO RECONHECIMENTO DE DIREITOS EXISTENCIAIS}

A análise cuidadosa dos possíveis dilemas surgidos a partir da relação travada entre Cinema e Literatura é primordial no reconhecimento de novos direitos. Parte-se da premissa conforme a qual o Cinema e a Literatura apresentam um papel de quebra de paradigmas e emergência de novas correntes reveladoras de mutações sociais. Por seu turno, o Direito, em sua concepção tradicional, funda-se no valor "segurança jurídica”. A jurisprudência aproxima-se das artes literárias e cinematográficas ao concatenar a aplicação do Direito ao contexto fático que funciona como elemento propulsor da máquina judiciária.

Um dos aspectos comuns da relação dialética travada entre literatura, cinema e Direito surge a partir de um elemento conciliador, qual seja: a linguagem. Neste sentido, observa-se que o Direito, a literatura e o cinema desenvolvem um papel primordial na interpretação dos fenômenos sócio-jurídicos bem como desenvolvem uma relação simbiôntica, na medida em que mantêm elementos integradores, tais como a linguagem, o objeto atrelado à depuração dos fatos sociais e o apelo artístico e cultural destinado ao público-alvo.

Na visão de Luis Alberto Warat (1985, pág. 100) não existem palavras inocentes. O espaço social onde elas são produzidas é condição da instauração das relações simbólicas de poder. A dimensão política da sociedade é também um jogo de significações. Isto supõe que a linguagem seja simultaneamente um suporte e um instrumento de relações moleculares de poder. Mas também um espaço de poder nela mesma. A sociedade como realidade simbólica é indivisível das funções políticas e os efeitos de poder das significações. 
A linguagem apresenta-se como elemento de integração entre o Direito, o Cinema e a Literatura. Partindo-se da análise linguística, verifica-se que o fenômeno jurídico pode ser observado de forma direta ou reflexa nos textos literários e cinematográficos, em múltiplos prismas.

Para Leon Tolstói (2016, pág. 59), assim como a palavra, transmitindo os pensamentos e experiências dos homens, serve para unir as pessoas, a arte serve exatamente da mesma forma. A peculiaridade desse meio de comunhão, que a distingue da comunhão por meio da palavra, é que pela palavra um homem transmite seus pensamentos a outro, enquanto que com a arte as pessoas transmitem seus sentimentos umas às outras.

A partir das premissas epistemológicas e linguísticas, percebe-se que um texto jurídico também apresenta nítido viés literário, na medida em que utiliza-se da narrativa, na descrição de fatos sociais, de forma sequencialmente concatenada, inclusive com personagens e enredo.

A realidade contemporânea pós-moderna exige do operador jurídico uma conduta despida de posições dogmáticas e exegéticas devendo manter-se aberto à evolução dos fatos sociais cada vez mais complexos e heterogêneos. A função social do profissional jurídico atrela-se ao desenvolvimento do bem comum na inclusão de cidadãos na fruição dos direitos fundamentais consagrados pelo Estado Democrático de Direito.

A análise crítica de filmes e obras literárias sob o enfoque hermenêutico jurídico-constitucional de apreensão dos direitos fundamentais serve de supedâneo à concatenação entre as características de sensibilidade e racionalidade exigidas do profissional jurídico e a complexidade dos novos fenômenos sociais por vezes tratados em obras artísticas e ignorados pela lei.

De forma não sistematizada observa-se que a utilização de análise de obras artísticas sob o viés jurídico-hermenêutico é bem antiga. Sobre o contributo da obra $O$ Mercador de Veneza, de William Shakespeare para o Direito, cuidou Rudolf Von Ihering (2005, pág. 22) 2 .

\footnotetext{
${ }^{2}$ Veja-se: "Fazemos votos de que parte do mérito alcançado por Shakespeare no terreno jurídico reverta em proveito do Colombo que descobriu esse novo mundo do direito, de cuja existência até então os círculos jurídicos não tinham o menor conhecimento. Segundo as normas que regem a descoberta do tesouro, ao descobridor caberia a metade. E como este lhe atribui um valor incomensurável, pode ele darse por satisfeito com a recompensa. Devo remeter o leitor ao trabalho desse autor para instruir-se sobre a 'enorme profusão de ideias jurídicas que Shakespeare derramou sobre a peça'. Da minha parte prefiro não
} 


\section{0 direito existencial à busca da felicidade na análise literária da obra o caçador de pipas, de Khaled Hosseini}

Como mecanismo organizado tem-se que uma das primeiras tentativas de união entre a Literatura e o Direito apareceu com o movimento denominado Law and Literature Movement, cujo objeto é a abordagem do Direito com supedâneo na Literatura. Traduz-se o movimento intitulado Law and Literature como um dos modos em que se plasma o Direito como Arte. Trata-se de modalidade de interpretação das normas jurídico-constitucionais a partir de mecanismos externos à Ciência Jurídica. O movimento ora em análise surgiu nos anos 1970, nos Estados Unidos da América. Sua sistematização, no entanto, deu-se apenas na década subsequente, e reverberou inclusive na Europa. No Brasil, Law and Literature está a carecer de uma maior análise, em que pese algumas iniciativas ocorridas mais recentemente por alguns Cursos Jurídicos. Como corolário da Law and Literature e acerca da relação simbiótica travada entre a interpretação literária e a hermenêutica jurídica tratou Ronald Dworkin (2.000, pág. 217) ${ }^{3}$.

As manifestações artísticas, em especial o Cinema e a Literatura humanizam o Direito, demonstrando que o Direito não se desvincula da realidade social que o circunda. A alteridade é um grande contributo que a Literatura e o Cinema podem atribuir ao Direito, já que a solidariedade e a sensibilidade são características escassas na realidade jurídica contemporânea.

Neste sentido, vaticina Leon Tolstói (2016, pág. 60): "Desde que os espectadores ou ouvintes sejam contagiados pelo mesmo sentimento que o autor experimentou, trata-se de arte".

Para François Ost $(2015, \text { p. } 155)^{4}$ o Direito, seleciona, estabelece hierarquias e cria regras, ao passo que a narrativa literária satisfaz um número infinito de "variações imaginativas".

recomendar à juventude dedicada ao estudo do direito que frequente a Escola de Portia para abeberar-se nas fontes do novo evangelho. Nem por isso, porém, deixo de render todas as homenagens à grande heroína da peça de Shakespeare".

${ }^{3}$ Observe-se, textualmente: "Sustentarei que a prática jurídica é um exercício de interpretação não apenas quando os juristas interpretam documentos ou leis específicas, mas de modo geral. O Direito, assim concebido, é profunda e inteiramente político. Juristas e juízes não podem evitar a política no sentido amplo da teoria política. Mas o Direito não é uma questão de política pessoal ou partidária, e uma crítica do Direito que não compreenda essa diferença fornecerá uma compreensão pobre e uma orientação mais pobre ainda. Proponho que podemos melhorar nossa compreensão do Direito comparando a interpretação jurídica com a interpretação de outros campos do conhecimento, especialmente a literatura. Também suponho que o Direito, sendo mais bem compreendido, propiciará um entendimento melhor do que é a interpretação em geral".

${ }^{4}$ Tradução livre: “... el Derecho selecciona, establece jerarquías y crea reglas, la narrativa literaria satisface un infinito de "variaciones imaginativas". 
A concretização da Ciência do Direito depende fundamentalmente da interpretação humana. A significação jurídica depende efetivamente do caráter valorativo, conforme apresenta a teoria filosófica. Para Ronald Dworkin (2.000, pág. 217): “... política, arte e Direito estão unidos, de algum modo, na filosofia”.

Por meio do cinema e da literatura como mecanismos de junção entre direito e arte, observam-se meios de comunicação capazes de modificar e constituir o discurso jurídico historicamente construído. Desta forma desenvolve-se uma relação simbiótica entre o Direito e as manifestações artísticas literárias e cinematográficas. Nesta questão desenvolve-se a questão atinente à construção de uma cidadania inclusiva, como expressão da hermenêutica mais efetiva dos direitos humanos fundamentais. Neste sentido, cinema, literatura e cosmovisão jurídicas contribuem na percepção dos clamores sociais impeditivos do gozo dos direitos fundamentais (quer sejam os individuais, sociais ou coletivos) na busca de uma sociedade menos excludente e mais justa.

A interpretação da linguagem é um aspecto comum à literatura, ao cinema, à cosmovisão e ao Direito. Através das artes, conseguem-se provocar nos receptores as mais diversas sensações que transcendem ao campo do racionalismo cartesiano, uma vez que as emoções campeiam nas manifestações artísticas.

Preleciona Benjamin Abdala Júnior (2.007, pág. 279) que o processo de escrita con-forma, assim, estratégias de um imaginário político, onde as imagens-ação recuperam peças definidoras da nação, para - na ação política/textual - construírem uma nova realidade (social, poética). Esta não se fixa no presente alienado, nem na utopia plenipotente, mítica, mas no processo de atualizações das formas do devir, nas redes articulatórias do texto. Para isso, a materialização desse devir acaba por deslocar o referente, pois que não é aspiração utópica, mas sua face concreta, "possível", dentro da dimensão histórica em que os escritores engajados colocam-se como atores sociais ativos.

À luz dos fatores já ventilados, tem-se a abordagem da questão hermenêutica, mais um ponto de semelhança entre o Direito, o Cinema e a Literatura, uma vez que uma das metas precípuas da interpretação jurídica é a identificação do significado, por meio de mecanismos como a valorização do ambiente.

Para Ronald Dworkin (2.000, pág. 221) seria bom que os juristas estudassem a interpretação literária e outras formas de interpretação artística. Isso pode 
parecer um mau conselho, pois os próprios críticos estão completamente divididos sobre o que é a interpretação literária, e a situação não é melhor nas outras artes. Mas é exatamente por isso que os juristas deveriam estudar esses debates. Nem todas as discussões na crítica literária são edificantes ou mesmo compreensíveis, mas na literatura foram defendidas muito mais teorias da interpretação que no Direito, inclusive teorias que contestam a distinção categórica entre descrição e valoração que debilitou a teoria jurídica.

Observa-se que, por meio da narrativa literária é possível chegar a determinadas conclusões em torno das relações político-sociais, bem como das representações jurídicas, que ultrapassam o momento imediato, proposto e observável. Daí surge a recomendação conforme a qual os juristas devam estudar não apenas a interpretação literária, mas outras formas de interpretação artística.

A análise literária propicia a construção de outro olhar em torno das questões sociais, econômicas, filosóficas, religiosas, políticas e jurídicas. A experiência da leitura desperta a sensibilidade, para além do plano meramente racional e cartesiano norteador da epistemologia contemporânea.

As artes, especialmente a literatura e o cinema servem como mecanismos de manifestação política de protesto, interpretando as profundas assimetrias que caracterizam a realidade contemporânea e desnudando a vulnerabilidade ante os desafios que se mostram para a humanidade.

Conforme o diagnóstico de Leon Tolstói (2016, pág. 51) uma definição da arte não existe; as existentes, tanto as metafísicas quanto as práticas, resumem-se a uma e mesma definição subjetiva, que, por mais estranho que possa ser, é a visão da arte como manifestação da beleza, e da beleza como aquilo que agrada (sem suscitar desejo). Muitos estetas perceberam a inadequação e a instabilidade de uma tal definição e, com o propósito de dar-lhe substância, perguntaram a si mesmos o que é agradável e por quê, transferindo assim a questão da beleza para o âmbito do gosto.

$\mathrm{O}$ cinema e a literatura propiciam referências à construção da argumentação jurídica. Essas manifestações artísticas tendem a sensibilizar os juristas, fazendo com que estes percebam a dimensão do outro (alteridade).

Consoante aduz Ruy Amado (2007, pág. 174) todo o projeto de sociedade mais justa e mais humana implica uma concepção e uma prática da cultura. E isto não é problema de especialistas. É tarefa de todos. 
Há um reclamo onipresente e atemporal na sociedade brasileira para que as leis e o sistema do Poder Judiciário funcionem de modo satisfatório. Os mecanismos só podem ser acionados quando existe um conhecimento das funções dos órgãos e instituições pelo cidadão comum. A partir da análise de obras artísticas (em especial filmes e livros) existe a possibilidade de o cidadão educar-se para a cidadania, conscientizando-se do seu papel de agente transformador da realidade complexa e excludente, especialmente quando se reconhecem novos direitos à luz da análise dessas obras artísticas.

Pode-se apontar a busca da felicidade como direito existencial onipresente na história humana, ainda carecedor de apurada análise na delimitação de seus contornos. Trata-se de orientação de vida com intensas repercussões no plano jurídico.

\section{CONTORNOS DO DIREITO EXISTENCIAL À BUSCA DA FELICIDADE}

Consoante esposado por Amartya Sen (2.011, págs. 307 e 308) é difícil negar que a felicidade seja extremamente importante e que temos muito boas razões para buscar promover a felicidade das pessoas, incluindo a nossa. Em outra passagem aduz Amartya Sen (2.011, pág. 310): por mais importante que seja, a felicidade dificilmente pode ser a única coisa que temos razão para valorizar, nem a única métrica para medir as outras coisas que valorizamos. Mas quando a "ser feliz" não é dado um papel tão imperialista, esse funcionamento humano pode ser visto, com boa razão, como muito importante, entre outros. A capacidade de ser feliz é também um aspecto fundamental da liberdade que temos boas razões para valorizar. A perspectiva da felicidade ilumina uma parte extremamente importante da vida humana.

$\mathrm{Na}$ Antiguidade, a filosofia de Aristóteles, já reconhecia que o bem soberano é a felicidade, para onde todas as demais questões tendem. Ela é caracterizada como um bem supremo por ser um bem em si. Observa-se na visão eudemônica (a eudaimonia grega, corresponde à felicidade) aristotélica que, é em busca da felicidade que se justifica a boa ação humana. Para Aristóteles (2002, pág. 49):

\footnotetext{
"Adicionalmente, consideramos ser a felicidade a mais desejável de todas as boas coisas sem que seja ela mesma estimada como uma entre as demais, pois se assim fosse ela estimada, está claro que deveríamos considerá-la mais desejável quando mesmo a mais ínfima das outras boas coisas a ela estivesse combinada, uma vez que a adição resultaria num total mais lato de bem, e de dois bens o maior é sempre o mais desejável. A felicidade, portanto, uma vez
} 
tendo sido considerada alguma coisa final, (completa) e auto-suficiente, é a finalidade visada por todas as ações".

Na concepção aristotélica, a felicidade idealizada como o bem supremo, deve ser o objetivo de todas as ações humanas, incluindo as ações políticas públicas praticadas pelo Estado. Conforme Aristóteles, para se atingir a felicidade suprema (finalidade precípua da Ética) três realizações devem ser necessariamente conquistadas, quais sejam: possuir bens materiais, ter prazer e possuir excelência moral e intelectual que devem ser concretizadas no cotidiano das pessoas.

A questão da busca da felicidade é tradicional no constitucionalismo ocidental tendo sido contemplada em sentido individual no No.: I da Declaração de Direitos do Bom Povo da Virgínia (Estados Unidos da América/1776): “Que todos os homens são, por natureza, igualmente livres e independentes, e têm certos direitos inatos, dos quais, quando entram em estado de sociedade, não podem por qualquer acordo privar ou despojar seus pósteros e que são: o gozo da vida e da liberdade com os meios de adquirir e de possuir a propriedade e de buscar e obter felicidade e segurança."

O ideal da busca da felicidade foi repetido no Preâmbulo da Declaração de Independência dos Estados Unidos em 04 de Julho de 1776: “Consideramos estas verdades como evidentes por si mesmas, que todos os homens são criados iguais, dotados pelo Criador de certos direitos inalienáveis, que entre estes estão a vida, a liberdade e a procura da felicidade".

$\mathrm{Na}$ transição da felicidade individual para a coletiva, o Preâmbulo da Declaração de Direitos do Homem e do Cidadão (França/1789) consagra que as reivindicações dos cidadãos, fundadas em princípios simples e incontestáveis, se dirijam sempre à conservação da Constituição e à felicidade geral.

De acordo com Paulo Bonavides (2015, págs. 159 e 160), o eudemonismo estatal tem na filosofia iluminista a justificação de seus postulados. Leibnitz, afagando sempre uma doutrina otimista da vida, foi, segundo, Ahrens, dos primeiros que vislumbraram na ciência do Estado, como nas ciências da natureza, um instrumento de melhoria e adiantamento da sociedade humana. A mesma visão eudemonística abrangelhe a ideia de direito. Wolf, por sua vez, desenvolveu a doutrina de Leibnitz, e, atendendo aos profundos impulsos da época, criou a teoria do Estado promotor da felicidade e do bem-estar social. O resultado foi a adoção do pensamento wolfiano pela filosofia do absolutismo iluminista que, valendo-se da salus publica como pretexto para 
reforço dos laços de autoridade e consolidação do poder, colocou o Estado acima do Direito. As consequências que daí advieram às liberdades civis são naturalmente claras, visto que aquelas ideias expõem o direito e a liberdade, em sua formação individualista a graves perigos. O Estado de Wolf se arroga o direito de compreender melhor que o indivíduo mesmo o que se há de entender por bem individual, e assume assim posição nitidamente protecionista de tutela aos direitos e interesses individuais. Reside na felicidade (felicitas), que se compõe de três dados fundamentais, o fim do Estado policial de Wolf: suficiência de vida, tranquilidade e segurança. Desde que se alcance esse alvo, a favor da pessoa humana, desce a liberdade a plano secundário.

Neste mesmo sentido vaticina o Preâmbulo da Constituição Francesa de 1958 que as queixas dos cidadãos, fundadas doravante sobre princípios simples e incontestáveis, estejam sempre voltadas para a manutenção da Constituição e a felicidade de todos.

Observa-se, portanto, que a felicidade passou da condição de "direito natural" para direito humano consagrado em diversos documentos de Direito Internacional, tornando-se direito fundamental normatizado em diversos ordenamentos jurídicos.

Na visão de Hans Kelsen (2001, pág. 04), o anseio por justiça é o eterno anseio do homem por felicidade. Não podendo encontrá-la como indivíduo isolado, procura essa felicidade na sociedade. Justiça é felicidade social, é a felicidade garantida por uma ordem social. Nesse sentido Platão identifica justiça a felicidade, quando afirma que só o justo é feliz e o injusto, infeliz.

Apresenta-se nítida a garantia da busca da felicidade na cultura jurídica ocidental desde as declarações de direitos oriundas das revoluções burguesas. Essa questão merece ser valorizada e priorizada pela epistemologia do Novo Constitucionalismo Democrático Latino-Americano.

A Constituição do Japão (1946) de nítida feição pacifista no contexto da rendição na Segunda Guerra Mundial, também consagra o ideal da busca da felicidade em seu Art.13: “Artigo 13. Todas as pessoas deverão ser respeitadas como indivíduos. O direito à vida, liberdade, a busca pela felicidade, contanto que não interfira ao bemestar público comum, serão de suprema consideração na legislação e em outras instâncias governamentais". 
No Brasil, a Constituição Federal de 1988 não garantiu expressamente em seu Texto o direito à busca da felicidade, mas incluiu a dignidade da pessoa humana como fundamento republicano que serve de fundamento axiológico à construção de uma sociedade eudemônica.

$\mathrm{O}$ direito existencial à busca da felicidade tem sido enfrentado pelos tribunais brasileiros, compondo a razão de decidir de importantes casos analisados no exercício da jurisdição constitucional.

O STF (RE 477554 AgR / MG, Relator: Min. Celso de Mello, julgamento: 16/08/2011, fonte: RTJ VOL-00220- PP-00572) ao reconhecer a possibilidade união civil entre pessoas do mesmo sexo firmou o entendimento consoante o qual o princípio constitucional da busca da felicidade, que decorre, por implicitude, do núcleo de que se irradia o postulado da dignidade da pessoa humana, assume papel de extremo relevo no processo de afirmação, gozo e expansão dos direitos fundamentais, qualificando-se, em função de sua própria teleologia, como fator de neutralização de práticas ou de omissões lesivas cuja ocorrência possa comprometer, afetar ou, até mesmo, esterilizar direitos e franquias individuais. Assiste, por isso mesmo, a todos, sem qualquer exclusão, o direito à busca da felicidade, verdadeiro postulado constitucional implícito, que se qualifica como expressão de uma ideia-força que deriva do princípio da essencial dignidade da pessoa humana.

A Proposta de Emenda à Constituição Federal de 1988 No.: 19/2010 direciona os direitos fundamentais sociais à realização da felicidade individual e coletiva. A PEC é de autoria do senador Cristovam Buarque, cujo objeto é a alteração do art. $6^{\circ}$ da Constituição Federal para direcionar os direitos sociais à realização da felicidade individual e coletiva.

Neste sentido deve-se ressalvar que a Assembleia Geral da ONU (2016, online) adotou em 19/07/2011 uma resolução para que os governos deem mais importância à felicidade e ao bem-estar na elaboração de políticas públicas para alcançar e medir o desenvolvimento econômico e social.

Por sugestão do Butão, que há muitos anos usa a Felicidade Interna Bruta (FIB) em vez do Produto Interno Bruto (PIB) como marcador de sucesso. A resolução sublinha que o indicador do PIB "não foi concebido para e não reflete adequadamente a felicidade e o bem-estar das pessoas" e "padrões insustentáveis de produção e consumo podem impedir o desenvolvimento sustentável”. 
Neste contexto deve-se ressaltar que o pequeno reino do Butão, situado na cordilheira do Himalaia (sul da Ásia), não é um país propriamente reconhecido pela abundância de riqueza e níveis satisfatórios de desenvolvimento econômico. Um aspecto relevante na construção da identidade e valores da população local foi a forte influência budista no país. O budismo, como religião e filosofia de vida, implica na definição de práticas e escolhas existenciais que permitam alcançar a Felicidade.

Quanto às escolhas existenciais elucida Eduardo Giannetti (2012, pág. 30) que o custo das escolhas seriamente inadequadas pode acarretar danos irreparáveis ao indivíduo e, no limite, a extinção da espécie. A tensão entre presente e futuro- agora, depois ou nunca- é uma questão de vida ou morte que permeia toda a cadeia do ser. Viver mais um dia, pelo tempo que for possível, e transmitir seu legado genético às gerações seguintes: os dilemas e encruzilhadas da troca intertemporal pontuam o trajeto de todos os seres vivos.

Neste contexto, os bens materiais devem ser procurados na medida em que tornam os seres humanos mais felizes e os auxiliam a encontrar seus objetivos, sendo um meio e não um fim. No pensamento budista, o luxo e a riqueza não são garantia de felicidade, sendo necessário para que se atinja tal desiderato um entendimento transcendente da realidade.

A Felicidade Interna Bruta (FIB) nasce em uma sociedade bastante carente, mas consciente que nem todos os parâmetros sem medem em parâmetros de consumismo e riqueza material. Acima de tudo prevalece a harmonia comunitária, a valorização da sua identidade e, sobretudo, a prevalência da vontade nacional sobre como o desenvolvimento deverá ser atingido. Observa-se, portanto a coincidência da busca da felicidade com os parâmetros da epistemologia do buen vivir adotada pelo Novo Constitucionalismo Democrático Latino-Americano.

A busca da felicidade (na qualidade de escolha existencial) se revestiu de um relevante status de importância singular na avaliação do bem-estar indispensável na delimitação do paradigma do buen vivir, colocando-a como a base da avaliação social e da elaboração de políticas públicas estatais.

Conforme aduz Amartya Sen (2.011, pág.265) o utilitarismo, iniciado por Jeremy Bentham, concentra-se na felicidade individual ou prazer (ou alguma outra interpretação da "utilidade" individual) como a melhor forma de avaliar a vantagem de como uma pessoa é e como isso se compara com as vantagens dos outros. 
A primazia exegético-dogmática da lei que vigorou durante o constitucionalismo liberal-clássico, relativizada no contexto do neoconstitucionalismo ao ceder espaço ao sopesamento de princípios com a valorização da dignidade da pessoa humana e dos direitos fundamentais de forma a albergar o direito à busca da felicidade, que merece ser incorporado e consolidado pela epistemologia do Novo Constitucionalismo Democrático Latino-Americano.

O direito à busca da felicidade decorre diretamente da implantação da epistemologia oriunda do aprimoramento da hermenêutica dos direitos fundamentais no neoconstitucionalismo, com a valorização da dignidade da pessoa humana, constituindo-se em genuíno direito fundamental que merece a sua incorporação ao paradigma do buen vivir, ínsito ao Novo Constitucionalismo Latino-Americano uma vez que defende a busca da realização pessoal dos indivíduos, dentro de um contexto de harmonia e complementaridade. Na contemporaneidade, a felicidade retoma uma significativa importância ao ser valorizada por diversos povos do mundo, de diferentes maneiras.

Vaticina Luis Alberto Warat (1990, pág. 27) que a pós-modernidade necessita de uma aliança de afetos que permita fazer do amor o sentido. Fazendo, assim, do amor, uma instância transformadora.

Neste sentido é válida a inclusão da busca da felicidade e do amor como valores informativos da epistemologia dessa nova corrente constitucional, na medida em que o Estado deve pautar-se por um constitucionalismo plural e aberto a estas inovadoras formas de resolver controvérsias jurídico-constitucionais. Neste jaez a ideia da busca da felicidade, decorre, por implicitude, do núcleo do qual se irradia o postulado da dignidade da pessoa humana, assume papel de extremo relevo no processo de afirmação, gozo e expansão dos direitos humanos fundamentais, qualificando-se, em função de sua própria teleologia, como fator de neutralização de práticas ou de omissões lesivas cuja ocorrência possa comprometer, afetar ou, até mesmo, esterilizar direitos e franquias individuais. Assiste, por isso mesmo, a todos, sem qualquer exclusão por força de suas escolhas existenciais do direito à busca da felicidade, verdadeiro postulado constitucional implícito, que se qualifica como expressão de uma ideia que deriva do princípio republicano dignidade da pessoa humana (Art. $1^{\circ}$-, inciso III da CF/88) e sua função instrumental. 
Para Hans Kelsen (2001, pág. 04), o conceito de felicidade deverá sofrer uma radical transformação de sentido, a fim de tornar-se uma categoria social: a felicidade da justiça. A metamorfose através da qual a felicidade individual e subjetiva se transforma na satisfação das necessidades reconhecidas socialmente se equipara àquela a que se deve sujeitar o conceito da liberdade a fim de tornar-se um princípio social; e o conceito de liberdade é frequentemente identificado com o de justiça, na medida em que uma ordem social é considerada justa se garantir a liberdade individual.

Ao analisar a constitucionalidade da Lei de Biossegurança (Lei No.: 11.105/2005) decidiu o STF que significa incorporar o advento do constitucionalismo fraternal às relações humanas, a traduzir verdadeira comunhão de vida ou vida social em clima de transbordante solidariedade em benefício da saúde e contra eventuais tramas do acaso e até dos golpes da própria natureza. Contexto de solidária, compassiva ou fraternal legalidade que, longe de traduzir desprezo ou desrespeito aos congelados embriões "in vitro", significa apreço e reverência a criaturas humanas que sofrem e se desesperam. Inexistência de ofensas ao direito à vida e da dignidade da pessoa humana, pois a pesquisa com células-tronco embrionárias (inviáveis biologicamente ou para os fins a que se destinam) significa a celebração solidária da vida e alento aos que se acham à margem do exercício concreto e inalienável dos direitos à felicidade e do viver com dignidade ${ }^{5}$.

A questão da busca da felicidade é a mola propulsora da humanidade - é ela que obriga os indivíduos a nortear todas as suas escolhas existenciais (estudar, trabalhar, constituir famílias). A insatisfação intrínseca ao ser humano revela que a cada vitória surge uma nova necessidade para o futuro.

Ao concatenar o valor justiça à busca da felicidade, assevera Hans Kelsen (2001, pág. 04): “O anseio por justiça é tão elementar, está tão profundamente enraizado no coração do homem, justamente por exprimir um anseio indestrutível da própria felicidade subjetiva".

Nessa relação simbiôntica travada entre a busca da felicidade e o valor do futuro aduz Eduardo Giannetti (2012, pág. 72):

Qual o valor do futuro? Qualquer que seja a resposta, o primeiro passo é ter alguma noção do que se entende especificamente por 'futuro'. Qual é- ou deveria ser- o horizonte de tempo relevante? Quantos lances à frente cumpriria ter em mente a cada novo lance da partida? A fome de futuro da

\footnotetext{
${ }^{5}$ Veja-se: STF- ADI 3510 / DF, Relator: Min. Ayres Britto, julgamento: 29/05/2008 . Fonte: DJe-096 DIVULG 27-05-2010 PUBLIC 28-05-2010.
} 
imaginação humana parece insaciável- índice da força do nosso apego e apetite por mais. O céu é o limite.

Observa-se, portanto, a necessidade do planejamento de metas viáveis para a consecução do direito existencial à busca da felicidade, de inegável caráter filosófico, social, jurídico e econômico.

\section{KHALED HOSSEINI E A SÍNTESE DA OBRA LITERÁRIA “O CAÇADOR DE PIPAS"}

$\mathrm{O}$ autor Khaled Hosseini (naturalizado estadunidense), nasceu no Afeganistão (na capital Cabul) em 1965. É um romancista e médico. Seu pai trabalhava como diplomata e sua mãe como professora de Literatura. Quando ele tinha 11 anos, a família se mudou para a França uma vez que seu pai foi convidado a trabalhar na embaixada afegã em Paris. O seu regresso estava previsto para 1980, mas, à época, o Afeganistão sofria a invasão soviética e um sangrento golpe de estado, pelo que a família Hosseini é obrigada a pedir asilo político aos Estados Unidos. Quatro anos mais tarde, pediu asilo nos Estados Unidos. Ele frequentou a escola nos Estados Unidos com pouco conhecimento da língua inglesa. Mudam-se então para San Diego e é lá que Khaled Hosseini gradua-se no curso de Medicina, na Universidade da Califórnia. Em 1993 começou a trabalhar como médico interno e em 1996, como físico. Em 2002 escreve o seu romance de estreia "The Kite Runner" (traduzido como "O caçador de pipas", no Brasil e "O menino de Cabul", em Portugal) que trata da amizade entre um jovem e o filho de seu criado, durante um período destrutivo da história do Afeganistão. Suas obras literárias transformaram-se em best-sellers. É casado com Roya Hosseini e tem dois filhos, Haris e Farah ${ }^{6}$.

Desde 2006, Khaled Hosseini é representante da Organização das Nações Unidas (ONU), fazendo de seus livros um canal de denúncias e engajamento social necessário para o debate de grandes questões morais e humanitárias que caracterizam o Século XXI. No caso específico da obra $O$ Caçador de Pipas dentre essas questões avultam em importância o direito existencial à busca da felicidade e os desafios enfrentados pelos refugiados.

$\mathrm{Na}$ infância, Khaled Hosseini leu desde poesias persas a romances ocidentais, como Alice no País das Maravilhas. As reminiscências de um Afeganistão

\footnotetext{
${ }^{6}$ Conferir: HOSSEINI, 2005.
} 
pré-invasão soviética e suas experiências pessoais o levaram a escrever o seu primeiro romance, intitulado: "The Kite runner" (O caçador de pipas).

Além de seu romance de estreia, $O$ Caçador de Pipas, que passou muitas semanas na lista de best sellers, o autor possui outros livros de sucesso, dentre eles " $A$ Thousand Splendid Suns", traduzido no Brasil como "A Cidade do Sol” e em Portugal como "Mil sóis resplandecentes", e o mais recente "O silêncio das montanhas". Juntos, seus romances venderam milhões de exemplares.

Assim como o protagonista de $O$ caçador de pipas, Khaled Hosseini deixou o Afeganistão na adolescência, mas o país define sua carreira e sua vida adulta. Ao substituir a Medicina pela Literatura como atividade profissional, o autor reconectou a sua vida ao país natal.

O livro $O$ caçador de pipas serviu como uma ponte entre os leitores ocidentais e a vida no Afeganistão. O país se tornou mais real para o mundo, bem como significou o resgate do elo do autor com seu país de origem.

$O$ caçador de pipas é considerado um dos maiores sucessos da literatura mundial na última década. O romance conta a história da amizade de Amir (interpretado no filme homônimo, por Zekeria Ebrahimi) e Hassan (papel de Ahmad Khan Mahmidzada) da etnia hazara, com origem humilde. São dois meninos quase da mesma idade, que apesar de habitarem na mesma casa têm vidas muito diferentes, no Afeganistão da década de 1970, onde existe uma forte divisão entre as classes sociais.

Amir é rico e bem-nascido, um protagonista que, no início, se mostra fraco e covarde, sempre buscando a aprovação de seu pai (essas características restam nítidas quando Hassan é vítima de abuso e Amir nada faz para ajudá-lo (2005, págs. 82 e 83): "Saí correndo porque era um covarde. Tinha medo de Assef e do que ele pudesse fazer comigo. Tinha medo de me machucar. Foi o que disse a mim mesmo quando dei as costas para o beco e para Hassan. Foi disso que me convenci.”). Por seu turno, Hassan, que não sabe ler nem escrever, é conhecido por coragem e bondade. Os dois, no entanto, são viciados em histórias antigas de grandes guerreiros, filmes de caubóis americanos e pipas.

Após a vitória em um torneio de pipas, no inverno de 1975, Hassan dá a Amir a chance de ser um grande homem, mas ele não enxerga essa possibilidade. Nesse momento, um ato torpe do personagem Assef, marca para sempre a vida e a relação entre Amir e Hassan. 
Hassan é violentado por Assef, e Amir não faz nada para defendê-lo (mesmo tendo a oportunidade de fazê-lo). A partir daí, os dois amigos se afastam e a consciência de Amir fica pesada. Então, Amir tenta por diversos meios afugentar sua culpa.

Anos depois quando a guerra que resultou da invasão da então União Soviética no Afeganistão acontece, Amir e o pai vão embora para os Estados Unidos tentando esquecer seu passado. A Guerra é apenas um pretexto para apresentar uma história cheia de mensagens sobre amizade, perdão, arrependimento.

$\mathrm{O}$ momento em que Amir e seu pai vivem com refugiados nos Estados Unidos é de privações e trabalho árduo. O pai começa a trabalhar em um posto de gasolina e toda a riqueza que os dois estavam acostumados tornou-se passado. Com o tempo, Amir se casa com Soraya (filha de afegãos), seu pai morre e ele se torna um escritor consagrado nos EUA. Apesar da aparente vida normal, a culpa ainda consome Amir.

Passados vinte anos, o destino fez com que Amir retornasse ao país natal para acertar contas com o passado. Amir recebe uma carta proveniente do Paquistão, de Rahim Kahn (amigo de seu falecido pai), pedindo para resgatar o filho de Hassan que está no Afeganistão. Depois de muito relutar, Amir vai para o Afeganistão e resgata o filho de Hassan, descobrindo que Hassan era seu irmão. O obstáculo posto como desafio é a necessidade de enfrentamento dos abusos cometidos pelo governo talibã no Afeganistão. Após muitas aventuras Amir consegue ficar em paz consigo.

$\mathrm{O}$ autor Khaled Hosseini desenvolveu um enredo emocionante e fascinante, com personagens fortes e cenas bem construídas, que provocam fortes sentimentos ao leitor, induzindo à reflexão. É importante ressaltar que a obra foi adaptada ao cinema, em 2007. O filme foi dirigido por Marc Forster. A obra literária, narrada em primeira pessoa por Amir, traz como uma de suas mensagens a leitura faz perceber que a vida é repleta de arrependimentos e perdões, mas, como saldo final a felicidade chega, mesmo tardiamente.

\section{O DIREITO EXISTENCIAL À BUSCA DA FELICIDADE NA OBRA “O CAÇADOR DE PIPAS"}

O deslocamento de Amir e seu pai como refugiados deu-se no intuito de fugir dos sofrimentos causados pela guerra, na busca da felicidade pelo amor. Nota-se 
que esse objetivo só veio a ser efetivamente atingido quando Amir faz as pazes com suas origens afegãs, resgata e adota Sohrab, o filho órfão de Hassan.

A busca da felicidade na obra $O$ Caçador de Pipas também é materializada quando Amir luta contra o regime Talibã no Afeganistão, especialmente no resgate de Sohrab das mãos de Assef. A sensação de libertação da criança pode significar o prenúncio da decadência desse regime autocrático no território afegão. Para Khaled Hosseini (2005, p. 289): "Lá no andar de cima, os gritos de Assef não paravam. Eram os berros de um animal ferido. Conseguimos chegar do lado de fora, ao ar livre, eu com o braço passado nos ombros de Sohrab, e vi Farid vir correndo na nossa direção".

Quanto aos horrores do terrorismo retratados na obra literária em análise, observa-se que a satisfação dos prazeres perversos pelo movimento fundamentalista islâmico Talibã não implica na sensação de ampliação da felicidade geral da população afegã. O usufruto de um prazer sádico torna pior a existência social. Desta forma, as condutas perversas e deletérias praticadas por grupos terroristas, afastam o direito existencial à felicidade. Constata Khaled Hosseini (2005, p. 245) que a infelicidade coletiva é retratada no estado deplorável no qual se encontra sua cidade natal após tantos anos de guerras: "Porque era comum haver atiradores escondidos atrás das árvores. Senti uma onda de tristeza. Estar de volta a Cabul era como ir ao encontro de um velho amigo que tínhamos esquecido, e ver que a vida não tinha sido boa para com ele; que tinha se tornado um indigente, um sem-teto."

O medo como técnica do governo radicalista também é um elemento impeditivo da felicidade existencial e coletiva. Nesse sentido, é circunstancial a fala do talibã Assef: “- Fomos de porta em porta, convocando os homens e os meninos. E os fuzilamos bem ali, na frente de suas famílias. Para que todos vissem. Para que se lembrassem de quem eram, qual era o seu lugar.”( Khaled Hosseini, 2005, p. 275).

Um exemplo do radicalismo talibã materializa-se na proibição de educação feminina. Nada no Islã afirma que as mulheres não podem ser educadas. Nenhum muçulmano informado acredita nisso. Dito isso, a história da menina paquistanesa Malala é um símbolo poderoso para quem acredita nas condutas terroristas e criminosas praticadas pelos talibãs. Nessa ordem de ideias, Khaled Hosseini (2005, p. 214) constata: "Algumas semanas depois, o Talibã proibiu as competições com as pipas. E, dois anos mais tarde, em 1998, eles massacraram os hazaras em Mazar-i-Sharif'. 


\title{
0 direito existencial à busca da felicidade na análise literária da obra o caçador de pipas, de Khaled Hosseini
}

É preciso compreender o Islã em uma nova realidade. Nesse sentido averbam Nathalie Bernard- Maugiron e Jean-Philippe Bras (2015, p. 4) ${ }^{7}$ o Islã contemporâneo, apreendido pela pós-modernidade, mobiliza a Sharia (Leis Islâmicas) em novas modalidades em suas redistribuições territoriais, mudanças econômicas e culturais, suas implicações nas transformações de ordem política global.

Em sua infância a busca da felicidade no personagem Amir, resumia-se em tentativas de agradar seu pai, que nunca repercutiam no resultado esperado. Assim encontra-se retratado no episódio do aniversário de treze anos do protagonista:

"Fiz TREZE ANOS NO VERÃO DE 1976, o penúltimo de um Afeganistão de paz e anonimato. As coisas entre mim e baba já estavam esfriando novamente. Acho que tudo começou com aquele estúpido comentário que fiz no dia em que estávamos plantando tulipas, aquela história de contratar empregados novos. Me arrependi de ter dito aquilo - me arrependi de verdade -, mas acho que, mesmo que não tivesse dito nada, o nosso pequeno interlúdio de felicidade ia se acabar de qualquer jeito. Talvez não tão depressa assim, mas ia acabar." (HOSSEINI, 2005, p. 98)

Ao se firmar como escritor e apresentar uma vida matrimonial estável em território estadunidense, a felicidade do protagonista também mostrou-se ilusória. Assim proclama Khaled Hosseini (2005, p. 185):

"Mais tarde, depois que Soraya pegou no sono - o vinho sempre a deixava sonolenta - fui para a varanda e fiquei respirando aquele ar fresco do verão. Lembrei de Rahim Khan e do bilhetinho de estímulo que tinha escrito depois de ler minha primeira história. E lembrei de Hassan. "Algum dia, Inshallah" você vai ser um grande escritor," foi o que ele me disse certa vez, "e gente do mundo todo vai ler as suas histórias". Tinha tanta coisa boa acontecendo na minha vida... Tanta felicidade... E fiquei me perguntando se eu merecia isso..."

A busca da felicidade pela ausência de guerras também se mostrou efêmera

e ilusória no intervalo entre o término dos conflitos pós- domínio soviético e a ascensão dos talibãs, conforme relato de Rahim Khan (2005, p. 214):

\begin{abstract}
"Já lhe disse que, em 1996, todos nós comemoramos quando os talibãs entraram em Cabul e acabaram com aqueles combates diários. Lembro que, naquela noite, cheguei em casa e vi Hassan na cozinha, ouvindo rádio. Seus olhos tinham um ar grave. Perguntei-lhe qual era o problema e ele apenas abanou a cabeça. 'Que Deus ajude os hazaras agora, Rahim Khan sahib disse ele. "'A guerra acabou, Hassan', retruquei. 'Vamos ter paz, Insballah! E felicidade, e calma. Acabaram-se os mísseis, acabaram-se as matanças, acabaram-se os funerais!' Ele, porém, se limitou a desligar o rádio e me perguntar se eu precisava de algo antes que fosse se deitar. "Algumas semanas depois, o Talibã proibiu as competições com as pipas. E, dois anos mais tarde, em 1998, eles massacraram os hazaras em Mazar-i-Sharif."
\end{abstract}

\footnotetext{
${ }^{7}$ Tradução livre: "l'Islam contemporain, saisi par la postmodernité, mobilise la charia sur de nouvelles modalités, dans ses redéploiements territoriaux, ses mutations économiques et culturelles, ses implications dans les transformations de l'ordre politique mondial."
} 
Após tantas tentativas frustradas o direito existencial à busca da felicidade só veio a ser atingido quando Amir, Soraya e Sohrab passam a conviver como família afetiva, superando um passado de abusos, guerras, conflitos, preconceitos e ódios. No episódio final, Amir e Sohrab soltam pipa em um parque, quando o primeiro constata: "Saí correndo, com o vento batendo no rosto e um sorriso tão grande quanto o vale do Panjsher nos lábios" (2005, p. 365).

\section{CONSIDERAÇÕES FINAIS}

O enfoque hermenêutico jurídico-constitucional de apreensão dos problemas abordados por obras literárias e cinematográficas serve de supedâneo à concatenação entre as características de sensibilidade e racionalidade exigidas do profissional jurídico e a complexidade dos fenômenos sociais surgidos há bastante tempo no plano dos fatos sociais e carecedores de proteção à luz dos ditames emanados do pós-positivismo.

Neste jaez, tem-se que os métodos de interpretação das normas jurídicas, estabelecidas pela Hermenêutica, vão admitir uma adaptação às situações impostas pelo caso concreto. A primazia exegético-dogmática da lei cede espaço ao sopesamento de princípios com a valorização da dignidade da pessoa humana e dos direitos fundamentais de forma a albergar a compreensão de fenômenos jurídicos pela Literatura e pelo Cinema.

A Ciência do Direito é dotada de um dinamismo que deve acompanhar a evolução dos fatos sociais, dotada de historicidade e, como tal necessita dos contributos extraídos a partir da Literatura e do Cinema para uma investigação transversal acerca de fatores extrajurídicos, a partir dos quais se configurou um viés mutacional na problemática de demandas imanentes aos mais diversos grupos sociais (incluindo os refugiados), com a necessidade de implementação de justiça fundada nos direitos fundamentais e da democracia inclusiva, na busca da concretização do direito existencial à felicidade, consagrado pelo constitucionalismo ocidental.

$\mathrm{O}$ enredo de $O$ Caçador de Pipas apresenta muitas coincidências com a trajetória do autor Khaled Hosseini. São vidas de refugiados afegãos que foram forçados por conflitos bélicos a estabelecer nova história em território estadunidense. Ambos transformaram-se em protagonistas a partir de seus trabalhos, revelando as atrocidades cometidas pelo regime talibã. No plano sentimental, também se verifica a mesma coincidência: ambos encontram-se em relacionamentos afetivos duradouros. 
Todo esse processo de materialização do direito existencial à busca da felicidade perpassa por uma análise contextual das tradições islâmicas. Busca-se ainda desmitificar o imaginário coletivo que associa o terrorismo e o radicalismo dos talibãs com a Sharia.

As inseguranças iniciais de Amir na desqualificação que ele fazia de seu amigo Hassan, consistiam em atribuir defeitos inexistentes e atribuição de menosprezo. Essa realidade destrutiva à alteridade fez com que ele se tornasse frustrado. Sua redenção rumo à felicidade plena só veio com o resgate do menino Sohrab, mediante o enfrentamento de todos os obstáculos, tornando-o, enfim, grandioso em sua felicidade individual e familiar.

\section{REFERÊNCIAS BIBLIOGRÁFICAS}

ABDALA JUNIOR, Benjamin. Literatura, história e política: literaturas de língua portuguesa no Século XX. $2^{\mathrm{a}}$ - edição. Cotia, SP: Ateliê Editorial, 2.007.

AMADO, Ruy. A Paixão da Arte. Lisboa: Edição do Autor (Gráfica 2000), 2007.

ARISTÓTELES. Ética a Nicômaco. Tradução: Edson Bini. Bauru, SP: EDIPRO, 2002. BONAVIDES, Paulo. Teoria Geral do Estado. 10ª- edição. São Paulo: Malheiros, 2015 .

DWORKIN, Ronald. Uma Questão de Princípio. Tradução: Luís Carlos Borges. 1 ${ }^{\text {a }}$ edição. São Paulo: Martins Fontes, 2.000.

GIANNETTI, Eduardo. O valor do amanhã: ensaios sobre a natureza dos juros. $2^{\mathrm{a}}$ edição. São Paulo: Companhia das Letras, 2012.

HOSSEINI, Khaled. O caçador de pipas. Tradução: Maria Helena Rouanet. Rio de Janeiro: Nova Fronteira, 2005.

KELSEN, Hans. O que é justiça? A justiça, o Direito e a Política no espelho da ciência. Tradução: Luís Carlos Borges. 3ª - edição. São Paulo: Martins Fontes, 2001.

MAUGIRON, Nathalie Bernard-; BRAS, Jean-Phiplippe. La charia. Paris: Éditions Dalloz, 2015.

OST, François. El reflejo del derecho en la literatura. ROGGERO, Jorge (compilador).

Decrecho y Literatura. Textos y contextos. Buenos Aires: EUDEBA, 2015.

SEN, Amartya. A ideia de justiça. Tradução: Denise Bottmann e Ricardo Doninelli Mendes. São Paulo: Companhia das Letras, 2.011.

TOLSTÓI, Leon. O que é arte?: a polêmica visão do autor de Guerra e Paz. Tradução: Bete Torii. 2a - edição. Rio de Janeiro: Nova Fronteira, 2016. 
VON IHERING, Rudolf. A Luta pelo Direito. Tradução: Pietro Nassetti. São Paulo: Martin Claret, 2.005.

WARAT, Luis Alberto. A ciência jurídica e seus dois maridos. Santa Cruz do Sul: Faculdades Integradas de Santa Cruz do Sul, 1985.

WARAT, Luis Alberto. O amor tomado pelo amor. Crônica de uma paixão desmedida. São Paulo: Acadêmica, 1990. 